\title{
On the Influence of Sudden Changes of Turgor and of Temperature on Growth.
}

BY

RODNEY H. TRUE, B.S., M.S.

\begin{abstract}
LTHOUGH growth, as influenced by external conditions, A has received much attention from plant-physiologists, a detailed study of the effects called forth by sudden change in these conditions has not yet been made.

The object of the investigation yielding the results given in the following pages was to ascertain more accurately the effects on growth brought about by sudden changes of turgor and of temperature. For the sake of convenience, the subjects will be treated separately.
\end{abstract}

\section{The Effect of Sudden Turgor Changes. Historical.}

Cohn ${ }^{1}$ seems to have first called attention to the effect of sudden changes of the concentration of the substratum upon organisms living in it. He found that either too rapid an increase or decrease of the concentration of the medium injured or killed Infusoria present, and he regarded the source of the injury to be the endosmotic processes taking place in the bodies of the animals.

Strasburger ${ }^{2}$ noted a very similar action in the case of swarm-spores.

${ }^{1}$ F. Cohn, Entwickelungsgeschichte der microscopischen Algen und Pilze. Nova Acta Akad. Caes. Leopold. Bd. XXIV (1854), Th. i, p. I32.

${ }^{2}$ E. Strasburger, Wirkung des Lichtes und der Wärme auf Schwärmsporen. Jenaische Zeitschrift für Naturwissenschaften, Bd. XII (I878), p. 66.

[Annals of Botany, Vo1. IX. No. XXXV. September, I895.

$\mathrm{D} d$ 
In experiments with plasmodia of Aethalium septicum, Stahl found that sudden changes of medium involving even as slight a difference as $0.25-0.5$ per cent. sugar were sufficient to fatally affect those parts of the plasmodia which were in contact with the solution. Stahl ${ }^{1}$ regarded the results seen as complicated phenomena of protoplasmic irritability.

Experiments involving similar changes of substratum have been made with Algae.

In studying the effects of a rapid increase or decrease of the salt-contents of the medium on marine Siphoneae, Noll ${ }^{2}$ found that the turgor-change in a mechanical way could even endanger the life of the organism. By suitable change of concentration, he found that the turgor-increase could be sufficient to rupture the cell-membrane.

When Fucus was treated in a similar manner, Oltmanns ${ }^{3}$ found that internal injury was produced, the medium becoming discoloured, probably by the colouring matter from the cells of the Alga. If the plants were not fatally injured, accommodation to the new medium took place, followed, after a time, by the return of normal growth.

Richter ${ }^{4}$ extended the study to fresh-water Algae, and obtained essentially like results.

Very similar results were earlier obtained by Eschenhagen ${ }^{5}$ in experiments made with moulds. A sudden transfer from one solution to another of sufficiently different sugar-content proved fatal, the bursting of the hyphal lips occurring as in the Siphoneae observed by Noll. If a less violent action took place, the hyphae assumed abnormal forms, but as accommodation became complete the usual shape and growth

${ }^{1}$ E. Stahl, Zur Biologie der Myxomyceten, Bot. Zeit., I884, p. I45.

${ }^{2}$ F. Noll, Beitrag zur Kenntnis der physikalischen Vorgänge, \&c. Arb. d. bot. Inst. in Würzburg, Bd. III (I 888), p. $49^{6}$.

${ }^{3} \mathrm{~F}$. Oltmanns, Ueber die Bedentung der Concentrationsänderung des Meerwassers für das Leben der Algen. Sitzb. d. Königl. preuss. Akad. d. Wissensch. zu Berlin, I89i, p. 193 .

4 A. Richter, Ueber die Anpassung der Süsswasseralgen an Kochsalzlösungen, Flora, I $89^{2}$, p. 4 .

${ }^{5}$ F. Eschenhagen, Ueber den Einfluss von Lösungen verschiedener Concentration auf das Wachsthum von Schimmelpilzen. Dissertation, Stolp, I889. 


\section{Turgor and of Temperature on Growth. 367}

were resumed. The causes here active receive further mention below.

Regarding the results of investigations made with higher plants, we find it noted by de Vries $^{1}$ that the growth of roots of seedlings and of stems in a 3 per cent. solution of $\mathrm{NaCl}$ was greater during the first twenty-four hours than during the like period immediately following. He further observed that the effect of a sudden change of turgor in the cells of certain flower stalks was similar to that noted in the Siphoneae and in the moulds. Upon washing out the tissues under the microscope, after five hours in a 7 per cent. $\mathrm{KNO}_{3}$ solution, many of the protoplasts were seen to burst before coming into contact with the cell-wall.

Stange ${ }^{2}$ observed that sudden changes of medium were fatal to roots of Vicia Faba, Pisum sativum, and Lupinus albus when the extremes of concentration involved were sufficiently removed from one another. Root-hairs were burst as a result of turgor-change.

From the observations cited, it appears that the condition of protoplasm and its rate of growth are more or less affected by a sudden change of the concentration of the substratum. In the cellular plants, as a result of the withdrawal of water from the cell-sap by an external solution of greater osmotic activity, the turgescence of the cells is diminished, and for mechanical reasons growth is either reduced or is stopped. On the other hand, a sudden increase of the water supply to a plant that has accommodated itself to a high concentration, causes the cells to take up water from the more dilute medium until an equilibrium is established. Thus the turgor pressure is increased, and an elongation due to this mechanical cause takes place, or tends to take place. It follows that the change of concentration must involve a certain minimum of difference, in order to call forth a noticeable change of length. The

${ }^{1} \mathrm{H}$. de Vries, Untersuchungen über die mechanischen Ursachen der Zellstreckung. Leipzig, 1877, p. 58 .

${ }^{2}$ B. Stange, Beziehung zwischen Substratconcentration, Turgor und Wachsthum bei einigen phanerogamen Pflanzen. Bot. Zeit. I892, p. 253.

D d 2 
magnitude of this minimal difference varies according to the properties of the membrane and of the protoplast.

From the above cited investigations, it seems that two kinds of results have been found to follow sudden changes of concentration. In the rupture of cell-membranes seen in the moulds and Algae, we have extreme cases of the mechanical effect of a sudden increase of turgor.

In the Myxomycetes, in which those tensions arising from the presence of a cell-membrane are done away with, we find the protoplasm free to respond by means of irritation movements. That, in the cellular plants, also, results due to the irritable nature of the protoplasm may likewise be present, but obscured more or less by the striking physical phenomena, is not to be forgotten. It would, indeed, seem probable that such is the case. It would, furthermore, be expected that these irritation-modifications would, in one way or another, find expression in the growth-rate, since this is the resultant of so many factors, and is, in so many directions, open to change-producing influences. The evidence bearing on this point is very incomplete. Oltmanns ${ }^{1}$ and Eschenhagen ${ }^{2}$ found a decreased rate of growth to follow sudden changes of the concentration of the substratum, but no systematic measurements show the extent or duration of such retardation.

\section{Materials and Methods.}

For the purposes of this investigation, the radicles of young seedlings were selected as the most desirable objects; and, owing to their superior ability to withstand the hard conditions necessarily offered in these experiments, those of Vicia Faba were generally used. Pisum sativum and Lupinus albus were used as objects for comparison. The seeds were soaked in water until swelled, and for further germination were placed in sawdust and kept at the ordinary room-temperature. After 40 to 45 hours, when the radicles were from I7 to $35 \mathrm{~mm}$. long, they were ready for use. In the investi-

1 Oltmanns, loc. cit., p. I94.

${ }^{2}$ Eschenhagen, loc. cit., p. 35 . 
gation only those specimens were used which, by at least an average growth, indicated a normal condition.

As the osmotically active agent, potassium nitrate in accurate solutions was used. By means of pieces of cork, to which the seedlings were fastened with iron pins or rubber bands, the plants were brought in perpendicular position into glass vessels containing the desired medium. Care was taken that the cotyledons were held above the surface and were kept sufficiently moist. Except at times of measurement, the vessels containing the seedlings were placed in a dark compartment, in which the temperature remained fairly constant or made very gradual changes. If not especially stated, the range of variation in 24 hours may be assumed to be between $17^{\circ}$ and $20^{\circ} \mathrm{C}$.

To obtain the general features of the curve, the growth and its distribution were measured in the usual manner by means of marks of India ink and a scale. The more detailed study of parts of the growth-curve was made with the horizontal microscope ${ }^{1}$. Two methods were used: (I) measurements were made from point to point, as described by Pfeffer $^{2}$, and (2) by the movement of the root-tip on the ocular micrometer. A discussion of these methods is given by Pfeffer (as cited), Askenasy ${ }^{3}$, and Francis Darwin ${ }^{4}$.

As the transfer from water to the saltpetre solution frequently caused a more or less complete obliteration of the ink marks, the latter method was here usually applied.

Some of the sources of error may here receive attention. As a sudden change of medium was necessary, experiments were conducted only in aqueous solutions with control-experiments in water. The evident advantages of this method seemed to justify its use in face of the fact that the growth-

1 Pfeffer, Pflanzenphysiologie. Leipzig, Bd. II, p. 84 (I88I).

${ }^{2}$ Pfeffer, Physiologische Untersuchungen. Leipzig, 1873, p. 27, also Druck und Arbeitsleistung durch wachsende Pflanzen. Abh. d. Königl. Sächs. Gesellsch. d. Wissensch. Bd. XX (I893), Heft 3, p. 293, Leipzig.

${ }^{3}$ E. Askenasy, Ueber einige Beziehungen zwischen Wachsthum und Temperatur. Ber. d. deutsch. bot. Gesellsch. VIII (1890), p. 61.

${ }^{t}$ F. Darwin, Arb. d. bot. Instit. in Würzburg, Bd. II, p. 52 I. 


\section{True.-On the Influence of Sudden Changes of}

rate was thereby considerably reduced when compared with that made in soil or sawdust ${ }^{1}$.

As pointed out by Askenasy ${ }^{2}$, the handling of roots incidental to measurement causes a decided disturbance of the growth. By quick and careful handling, it was sought to reduce this to a minimum. As all roots used were as nearly alike as was practicable to choose them, and as the method of handling was as nearly the same in all cases as possible, the results may be regarded as comparable. Because of this fact, and because of the relative nature of the question under discussion, the above errors may the more easily be neglected.

\section{Experimental.}

Turning now to the experimental part of our subject, it seems well at the beginning to notice briefly the growth observed under normal conditions.

In the following experiment the growth of four roots of Vicia Faba was observed for a period of approximately I 2 days. The temperature varied between $18^{\circ}$ and $20^{\circ} \mathrm{C}$. The average total length of the roots at the beginning of the experiment was about $20 \mathrm{~mm}$.

Table I shows a summary of the results.

In the left column, designated 'Period,' is indicated the duration of time in hours and minutes elapsing between measurements. In the middle column is shown the rate of growth in millimetres per hour, found to prevail during the given periods. At the right, the medium used is noted, here water during the entire experiment. The first line of the table, therefore, shows that during the period of $\mathrm{I}_{4}^{\frac{3}{4}}$ hours after the beginning of the experiment, the average growth-rate per hour was $0.50 \mathrm{~mm}$. in water as a medium.

The very flat curve rises irregularly to a maximum indicating a growth-rate of about $\mathrm{I} \mathrm{mm}$. per hour. By an average temperature of $19^{\circ} \mathrm{C}$. it is attained in from 130 to 150 hours after

${ }^{1} \mathrm{~J}$. Sachs, Gesammelte Abhandhungen über Pflanzenphysiologie, Bd. II, p. $79^{6}$.

${ }_{2}$ Askenasy, loc. cit. 
the swelled seeds are placed in the sawdust. About one day before the maximum is reached, protuberances indicate the internal formation of lateral roots, which burst through and begin a rapid growth, the oldest attaining an average length of about Io $\mathrm{mm}$. by the time the primary root has reached its maximum rate. From this time on, the demands of the laterals cause the curve to fall.

TABLE I.

\begin{tabular}{|rr|cc|c|}
\hline \multicolumn{2}{|c|}{ Period. } & Growth per hr. & Medium. \\
\cline { 2 - 4 } Hours. & Min. & & & \\
I & 45 & 0.50 & $\mathrm{~mm}$. & Water \\
I 7 & 00 & 0.75 &, &, \\
6 & 00 & 0.65 &, &, \\
I 7 & I5 & 0.65 &, &, \\
23 & 15 & 0.80 &, &, \\
24 & 00 & 0.97 &, &, \\
25 & 30 & 0.98 &, &, \\
47 & 30 & 0.72 &, &, \\
24 & 30 & 0.56 &, &, \\
47 & 45 & 0.58 &, &, \\
50 & 00 & 0.59 &, &, \\
\hline
\end{tabular}

Passing now to the consideration of the effect of changes of concentration of the medium on growth, it may be said, a priori, that two factors enter into the question; (I) the length of time during which the objects are exposed to the action of the various culture-mediums, and (2) the degree of concentration of the same.

In order to roughly determine what degree of concentration could be endured, and for how long, seedlings of Vicia Faba were brought into saltpetre solutions of $3 \cdot 0,1 \cdot 5, \mathrm{I} \cdot 0$, and 0.25 per cent. respectively. Three per cent. was found to be speedily fatal in its action. If the exposure in $\mathrm{I} \cdot 5$ per cent. was for a short time only, the transfer to water was followed tardily by returning growth ; if the exposure was prolonged, 


\section{True.-On the Influence of Sudden Changes of}

the root-tips died. In solutions of a $\mathrm{I} \cdot \mathrm{O}$ per cent. concentration or less, accommodation and further growth took place.

That, by a gradual increase of concentration, growth in mediums which here proved fatal could take place, is certain ${ }^{1}$.

Pisum sativum and Lupinus albus were found to be more sensitive than Vicia Faba. Indeed, Lupinus was more strongly affected by a 0.25 per cent. solution than Vicia Faba by one of $\mathrm{I} \cdot \mathrm{O}$ per cent. $\mathrm{KNO}_{3}$ content.

Table II shows the average growth of six roots of Vicia Faba in a $\mathrm{I} \cdot \mathrm{O}$ per cent. saltpetre solution for 4 days. Temperature $17.0^{\circ}$ to $18.9^{\circ} \mathrm{C}$.

TABLE II.

\begin{tabular}{|cc|cc|c|}
\hline \multicolumn{2}{|c|}{ Period. } & Growth per hr. & Medium. \\
\cline { 1 - 3 } Hours. & Min. & & & \\
3 & 30 & $*_{0.2}$ & $\mathrm{~mm}$. & $\mathrm{KNO}_{3}(\mathrm{I} \%)$ \\
3 & 05 & 0.48 &, & $"$ \\
3 & $\mathrm{I} 0$ & 0.63 &, &, \\
$\mathrm{I} 7$ & 00 & 0.62 &, &, \\
23 & $\mathrm{I} 5$ & 0.52 &, &, \\
24 & $\mathrm{I} 5$ & 0.55 &, & $"$ \\
23 & 45 & 0.49 &, &, \\
\hline
\end{tabular}

* Estimated average contraction.

In order to obtain approximately the extent of the contraction due to the turgor-reducing action of the $\mathrm{KNO}_{3}$ solution, a measurement was made 30 minutes after the transfer to the medium. Although decimal parts less than $0.5 \mathrm{~mm}$. are questionably near the limit of accuracy with the scale, still the average contraction has been given as estimated. It seemed to me that the estimates were nearer the truth than either the nearest unit or half unit. A further discussion of this feature is reserved for a later part of this paper, where the results of measurement with the horizontal microscope receive attention.

\footnotetext{
${ }^{1}$ Stange, loc. cit.
} 
A comparison of the curve of growth here found with that of normal growth in water brings forth one striking difference. In the I per cent. solution, the curve does not rise to the usual maximum. The process of accommodation takes place quickly, after $3 \frac{1}{2}$ hours at most, the rate of growth being plainly equal to the normal. As remarked by de Vries ${ }^{1}$, however, in similar experiments, the growth of the second day is reduced. During the remainder of the experiment, the curve rises at no time to a higher point than that reached immediately after the accommodation to the new medium had taken place. The resulting total growth is, therefore, decidedly smaller than that characteristic for the control in water for a like length of time.

TABLE III.

\begin{tabular}{|c|c|c|c|c|c|}
\hline \multicolumn{2}{|c|}{ Period. } & \multicolumn{2}{|c|}{ Growth per hr. } & \multicolumn{2}{|c|}{ Medium. } \\
\hline Hours. & $\begin{array}{c}\text { Min. } \\
30\end{array}$ & *o.10 $\mathrm{r}$ & $\mathrm{nm}$. & 0.25 & $\mathrm{KNO}_{3}$ \\
\hline 2 & 30 & 0.45 & , & , & " \\
\hline 2 & 30 & 0.70 & , & ", & , \\
\hline 15 & 45 & 0.73 & , & " & , \\
\hline 23 & 45 & 0.54 & , & ", & ", \\
\hline 27 & ০০ & 0.30 & , & " & $"$ \\
\hline 20 & I 5 & 0.16 & , &, & ", \\
\hline 24 & 45 & 0.05 & , & ", & ” \\
\hline 29 & $\infty$ & 0.00 & , & , & , \\
\hline
\end{tabular}

* Estimated average contraction.

For comparison, Table III, showing the average growth-rates of a series of four radicles of Lupinus albus in a 0.25 per cent. $\mathrm{KNO}_{3}$ solution, is here given. Temperature $\mathrm{I} 7.0^{\circ}$ to $\mathrm{I} 9.5^{\circ} \mathrm{C}$.

The same general course seen in the last experiment is here repeated. A rather rapid accommodation, approximately normal growth for nearly a day, then a gradual and continued decrease with a much reduced total growth, are the features to be noticed.

\footnotetext{
${ }^{1}$ De Vries, loc. cit., p. $5^{8}$
} 


\section{True.-On the Influence of Sudden Changes of}

That the radicles were strongly affected by the solution is seen in the forms they assumed. Swellings appeared near the tips, and the ends tapered suddenly to sharp points. On the other hand, the growth in thickness was much greater than normal, the radicles above the swellings reaching the size of large radicles of Vicia Faba of the same length.

A similar but very much more decided effect is noted by Wieler ${ }^{1}$ in radicles of Phaseolus multiflorus grown in glycerine.

Stange ${ }^{2}$ also mentions similar appearances in radicles grown in a medium containing glycerine.

Roots of Vicia Faba grown in a 0.25 per cent. solution of $\mathrm{KNO}_{3}$ gave a practically normal growth-curve.

We will now turn to the experiments bearing on the question as to the effect of sudden turgor-changes on growth. Seedlings taken from the sawdust were marked and placed in water for a short time, perhaps one or two hours. This gave an opportunity for such changes as might arise from the modified conditions of water ${ }^{3}$ and oxygen supply to take place. The roots were then measured, and transferred directly to the desired medium. Those placed in saltpetre solutions were allowed to remain for various lengths of time, from i to 72 hours. At the expiration of these periods of exposure, the return to water was suddenly made. Care was always taken that the same temperature prevailed in the different mediums. About 30 minutes after a change of substratum, measurements were made to ascertain the amount of elastic contraction or elongation due to turgor-change. Further measurements were made at suitable intervals to obtain growth-rates.

Those experiments involving the most decided changes are considered first.

In Table IV are given the average growth-rates of a series of roots of Vicia Faba during an exposure of 72 hours to

1 Wieler, Ueber Anlage und Ausbildung von Libriformfasern in Abhängigkeit von äusseren Verhältnissen, Bot. Zeit. I889, p. 25 o.

${ }^{2}$ Stange, loc. cit.

${ }^{3}$ Compare Duhamel, Naturgeschichte der Bäume, Bd. I (I 764$)$, p. I07. Sachs, Gesammelte Abhandlungen, Bd. II, p. 785 . 
a I. $\circ$ per cent. $\mathrm{KNO}_{3}$ solution, and during the 9 days following the sudden transfer to water. The averages are drawn from but three specimens, one showing pathological symptoms after the transfer to water being excluded.

TABLE IV.

\begin{tabular}{|c|c|c|c|c|}
\hline \multicolumn{2}{|c|}{ Period. } & Growth per hr. & Medium. & Ternperature. \\
\hline Hours. & $\begin{array}{c}\text { Min. } \\
30\end{array}$ & $*_{0.30 \mathrm{~mm} .}$ & $\mathrm{I} \% \mathrm{KNO}_{3}$ & I $8.0 \mathrm{C}$. \\
\hline 3 & ০o & $0.05 \quad$, & " & I 8.2, \\
\hline 2 & 45 & $0.65 "$ & , & 17.5, \\
\hline I 7 & $\infty$ & $0.55 \quad$ & , & I 7.0, \\
\hline 26 & ০০ & $0.50 \quad$, & ", & I $7 \cdot 2$, \\
\hline 22 & I 5 & $0.40 "$ & & I $7 \cdot 2, "$ \\
\hline & $3^{\circ}$ & $+0.20 "$ & Water & I $7 \cdot 8$, \\
\hline 3 & 30 & $0.40 \quad$, & ", & $17 \cdot 8$, \\
\hline 2 & 45 & 0.20, & , & I $7 \cdot 8$, \\
\hline 16 & 45 & $0.50 \quad "$ & , & I $7 \cdot 5$, \\
\hline 23 & 45 & 0.75, & " & 16.5, \\
\hline 24 & ০০ & $0.55 \quad "$ & $"$ & I6.4 " \\
\hline 25 & 30 & $0.70, "$ & " & 16.5, \\
\hline 22 & 30 & $0.70 \quad "$ & ", & I6.5 , \\
\hline 24 & $\infty$ & 0.70, & ," & $17 \cdot 2$, \\
\hline 23 & 30 & $0.80 \quad$, & ," & I 7.5, \\
\hline 24 & I 5 & $0.55 \quad$ & ," & I 8.0, \\
\hline 23 & 30 & $0.40 "$ & " & 18.0, \\
\hline
\end{tabular}

As before remarked, the elastic elongation and contraction due to turgor-changes are here only estimated, and conclusions regarding these features of the experiment are to be drawn only from measurements made by means of the horizontal microscope.

The transfer to the $\mathrm{KNO}_{3}$ solution is here again followed by a short period of depression, which gives way to a normal growth-rate after about three hours. As seen in Tables I and 


\section{True.-On the Influence of Sudden Changes of}

II, so here, this normal rate is only temporary, the curve again beginning to sink. The transfer to water is seen to be followed, not immediately by a growth-rate characteristic of this medium, but by a retarded growth. Only after about 20 hours has the normal rate been established. Indeed, the roots seem to have been permanently affected, since the maximum rate reached is considerably less than in normal roots grown in water.

In a duplicate experiment with roots of Pisum sativum, the curve ran parallel to the preceding until the change to water

TABLE V.

\begin{tabular}{|c|c|c|c|c|c|}
\hline \multicolumn{2}{|c|}{ Period. } & \multicolumn{2}{|c|}{ Growth per hr. } & Medium. & Temperature. \\
\hline Hours. & $\begin{array}{c}\text { Min. } \\
30\end{array}$ & $0.00 \mathrm{n}$ & $\mathrm{nm}$. & $\mathrm{I} \% \mathrm{KNO}_{3}$ & I9. $5^{\circ} \mathrm{C}$. \\
\hline 3 & 30 & 0.20 & , & , & I9.6 , \\
\hline 2 & 30 & 0.65 & , & ", & I9.7 , \\
\hline I 6 & 30 & 0.70 & " & , & 19.2, \\
\hline 22 & 45 & 0.65 & , & , & I8.6, \\
\hline$\ldots$ & 30 & +0.25 & , & Water & 19.0, \\
\hline 2 & ${ }^{1} 5$ & 0.10 & " & , & I9.0, \\
\hline 5 & $\infty$ & 0.25 & , & ", & I9.0, \\
\hline 16 & 30 & 0.60 & , & ", & 18.0, \\
\hline 24 & 30 & 0.90 & ", & " & I 8.0, \\
\hline 24 & ০ & $I \cdot 05$ & , & , & I $7.5 \%$ \\
\hline 26 & ০০ & $\mathrm{I} \cdot 05$ & , & ", & I6.8, \\
\hline 22 & ০০ & $\mathrm{I} \cdot \mathrm{IO}$ & $"$ & ," & $\mathrm{I} 7 \cdot 2$, \\
\hline 24 & $\infty$ & 0.95 & ", & , & I6.5, \\
\hline 24 & I 5 & 0.75 & ", & , & I 6.2, \\
\hline
\end{tabular}

† Estimated average elongation.

was made. Recovery in water was not possible, and after five days of about one-fourth normal growth, the curve sank to the minimum.

In Table $\mathrm{V}$ are given the growth-rates of a series of roots of Vicia Faba during and following an exposure of 46 hours to a i per cent. solution of the usual salt. The series, origin- 


\section{Turgor and of Temperature on Growth. 377}

ally consisting of four radicles, was reduced to two by the appearance of abnormalities shortly after the transfer to water. The roots made the sharp curves characteristic of injury, and in aggravated cases, groups of dead cells could be distinguished on the concave side. The cause of this lies probably in the local inability of the surface-tissues to accommodate themselves to the sudden change of conditions. As the remaining radicles agreed very closely in their behaviour, the results are here given.

No measurable contraction was here seen to follow the

TABLE VI.

\begin{tabular}{|c|c|c|c|c|}
\hline \multicolumn{2}{|c|}{ Period. } & Growth per hr. & Medium. & Temperature. \\
\hline Hours. & Min. & $*_{0.25} \mathrm{~mm}$ & $\mathrm{I} \% \mathrm{KNO}_{3}$ & $18.0^{\circ} \mathrm{C}$. \\
\hline I & Io & $0.32 "$ & ” & 18.0, \\
\hline 17 & ০০ & 0.55, & , , , & I 8.0, \\
\hline & 35 & $+0.37 "$ & Water & I 8.0, \\
\hline 2 & 30 & 0.25, & , & I 8.0, \\
\hline 2 & 45 & $0.31 \quad$, & , & I 7.5, \\
\hline 17 & I5 & $0.48 \quad$, & , & I 7.0, \\
\hline 23 & I 5 & 0.68, & , & 17.5, \\
\hline 24 & $\infty$ & I.IO , & , & I 8.0, \\
\hline 25 & $3^{\circ}$ & I.I5 , , & , & I 8. \\
\hline 47 & 30 & I.02, & , & I 8.5, \\
\hline 24 & $3^{\circ}$ & $0.80, "$ & , & I 8.8, \\
\hline 47 & 30 & $0.80 "$ & $"$ & I 8.5, \\
\hline 50 & $\infty$ & $0.73,$, & , & I 8.0, \\
\hline
\end{tabular}

transfer to the salt solution. It was occasionally noticed that in very strongly growing roots, simply a check of the growth occurred. In such cases, the resultant of the growth and of the opposing action of the salt was nearly zero. Except in this particular, the results resemble those of the preceding experiment. The accommodation to water is more readily 


\section{True.- On the Influence of Sudden Changes of}

made, and no permanent injury is to be seen. After 8 hours in water, the normal growth-rate is re-established, and recovery is complete. Indeed, the maximum rate is greater than that of the average control-experiment in water.

Table VI shows the course of the growth of the four Vicia Faba roots during and after an exposure of 19 hours in the usual solution.

A comparison with Table $\mathrm{V}$ shows that in both cases the course of the growth-curve offers no essential difference from the preceding. The growth of the average control is here again exceeded at the maximum period.

TABLE VII.

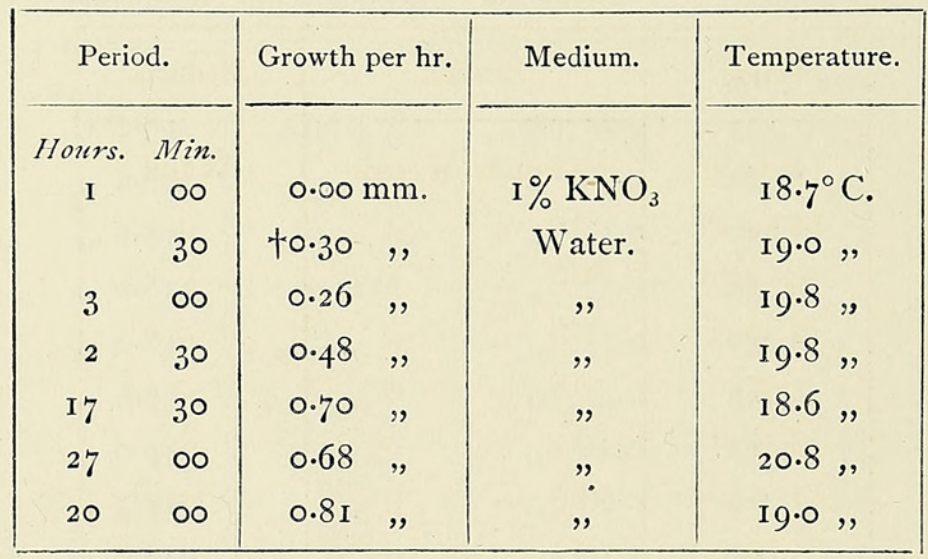

+ Estimated average elongation.

In order to obtain an idea of the minimum period of exposure sufficient to produce a retardation of the growthrate following the sudden return to water, experiments were made in which the roots were placed in the saltpetre solution for a short period.

A series of roots of Vicia Faba was placed in a I per cent. solution one hour, then suddenly transferred to water. No manifest retardation was observed. When, however, a concentration of 1.5 per cent. was used for the same length of time, a decidedly reduced growth-rate was seen to follow the transfer to water. Only after several hours was the normal growth-rate restored. 
Turgor and of Temperature on Growth. 379

Owing to its greater sensitiveness, a series of radicles of Lupinus albus gave a decided reaction after one hour in a I per cent. solution.

In Table VII are shown the details. The averages are drawn from 4 specimens.

During the hour spent in the $\mathrm{KNO}_{3}$ solution, the operative factors give as a resultant no measurable change of length. The mechanical contraction due to the turgor-change is approximately balanced by the slight growth following. The return to water is seen to be followed by a decided reaction.

It seems hardly probable that here we have, indeed, the simple result of the change from $\mathrm{KNO}_{3}$ to water. In view

TABLE VIII.

\begin{tabular}{|c|c|c|c|c|}
\hline Period. & \multicolumn{3}{|c|}{ Growth. } & Medium. \\
\hline I I $-\mathrm{II} \cdot 30$ & \multicolumn{3}{|c|}{ I 8 units of scale } & Water \\
\hline II $30-12$ & IO & $"$ & $"$ & ", \\
\hline I $2-2.30$ & $*_{\mathrm{I} 6}$ & ," & ", & $"$ \\
\hline $2 \cdot 30-3$ & 26 & ", & ", & , \\
\hline $3-3 \cdot 30$ & 18 & , & , & " \\
\hline $3 \cdot 30-4$ & 22 & , & " & , \\
\hline $4-4 \cdot 3 \circ$ & 25 & ", & $"$ & $"$ \\
\hline $4 \cdot 3^{\circ}-5$ & $2 I$ & $"$ & , & , \\
\hline $5-5 \cdot 30$ & 24 & , & ", & ," \\
\hline $5 \cdot 30-6$ & 25 & , & , & , \\
\hline $6-6.30$ & 29 & , & " & $"$ \\
\hline $6.30-7$ & 26 & ,, & ", & , \\
\hline
\end{tabular}

* Rate of growth per half-hour. I unit of scale $=0.0169 \mathrm{~mm}$.

of the short time elapsing after the transfer to the $\mathrm{KNO}_{3}$ solution, it is likely that before recovery from this shock has taken place, the second change of substratum occurs, and the retardation observed is probably the reaction to both stimuli. An analysis into the components was not attempted.

It appears, as would be expected, that the stimulus can be so reduced that no measurable reaction can be detected by measurements made with the scale. 


\section{True.-On the Influence of Sudden Changes of}

Passing to the experiments involving the use of the horizontal microscope, attention is first called to the normal growth as observed in control-experiments in water.

In Table VIII are shown the increments of growth made by a root of Vicia Faba, as determined by half-hourly observations. The total length of the root at the beginning of the experiment was $23 \mathrm{~mm}$. Temperature, $20.0^{\circ}-23.0^{\circ} \mathrm{C}$.

As was above suggested, if a root growing in sawdust be brought into water, a slight elongation is usually seen to occur, due to the swelling of the cell-membranes and to a slight increase of turgor-pressure in case the object was not already fully turgescent. This elongation is usually followed by a

TABLE IX.

\begin{tabular}{|c|c|c|c|}
\hline Period. & \multicolumn{2}{|r|}{ Growth. } & Medium. \\
\hline I I-I I.30 & \multicolumn{2}{|c|}{ I 6.0 units of scale } & Water \\
\hline II. $30-12$ & I 7.0 & ,, & , \\
\hline I 2-I 2.30 & 3.5 & ” & $\mathrm{I} \% \mathrm{KNO}_{3}$ \\
\hline I $2.30-1$ & $7 \cdot 5$ & ", & , \\
\hline $\mathrm{I}-2.30$ & $*_{\text {I } 3 \cdot 0}$ & $"$ & " \\
\hline $2 \cdot 30-3$ & I $7 \cdot 0$ & ” & $"$ \\
\hline $3-3 \cdot 30$ & $23 \cdot 0$ & $"$ & , \\
\hline $3 \cdot 30-4$ & $27 \cdot 0$ & ", & $"$ \\
\hline $4-4 \cdot 30$ & $45 \cdot 0$ & ," & Water \\
\hline $4 \cdot 30-5$ & 26.0 & , & $"$ \\
\hline
\end{tabular}

* Rate per half-hour. I unit of scale $=0.0169 \mathrm{~mm}$.

somewhat retarded rate of growth, arising probably as an irritative response to the changed conditions of water and of oxygen-supply. After an hour or two, the normal rate is generally restored.

It may also be mentioned here that the transfer of a root from the sawdust to the observation vessel involves a great change in the conditions of illumination. Whether roots are in any considerable degree sensitive to sudden changes of this nature seems to be a question that has not yet received attention.

In Table IX is shown the course of growth of a root of 
Turgor and of Temperature on Growth. $38 \mathrm{I}$

Vicia Faba in water and in I per cent. $\mathrm{KNO}_{3}$. Total length of root, $25 \mathrm{~mm}$. Temperature, $17 \cdot 0^{\circ}-19 \cdot 5^{\circ} \mathrm{C}$.

The transfer to the saltpetre solution is here followed by no noticeable contraction; the growth is simply checked. The gradual recovery of growth in the salt-solution is complete in about $2 \frac{1}{2}$ hours. The return to water is immediately followed by the elastic elongation due to the increased turgorpressure. Of the 45 units of increased length seen, 25 are added during the Io minutes following the change, seeming, therefore, to be, for the most part, due to the elastic extension

TABLE X.

\begin{tabular}{|c|c|c|c|c|}
\hline Period. & \multicolumn{3}{|c|}{ Growth. } & Medium. \\
\hline $10.30-11$ & \multicolumn{3}{|c|}{ I 5.0 units of scale } & Water \\
\hline I I -11 I. 30 & I $3 \cdot 0$ & ", & $"$ & ," \\
\hline II. $30-I^{2}$ & 16.0 & $"$ & " & ", \\
\hline $12-2.30$ & $*_{1} 4 \cdot 0$ & ", & " & , \\
\hline $2.30-3$ & $-8 \cdot 0$ & $"$ & ” & $1 \% \mathrm{KNO}_{3}$ \\
\hline $3-3 \cdot 30$ & 6.0 & " & , & , \\
\hline $3 \cdot 30-4$ & $5 \cdot 5$ & , & ", & , \\
\hline $4-4 \cdot 3 \circ$ & $4 \cdot 0$ & $"$ & , & $"$ \\
\hline $4 \cdot 30-5$ & $3 \cdot 0$ & ” & ” & $"$ \\
\hline $5-5 \cdot 30$ & $3 \cdot 0$ & ", & , & , \\
\hline $5 \cdot 30-6$ & $2 \cdot 0$ & ", & , & , \\
\hline $6-6.30$ & $25 \cdot 0$ & , ' & ", & Water \\
\hline $6.30-7$ & $5 \cdot 0$ & $"$ & $"$ & $"$ \\
\hline $7-7 \cdot 30$ & $2 \cdot 0$ & $"$ & , & , \\
\hline
\end{tabular}

* Rate per half-hour. I unit of scale $=0.0182 \mathrm{~mm}$.

caused by turgor. During the hour following the return to water, no retardation of the growth-rate is seen. That it may have occurred later had the experiment been prolonged is of course possible.

For comparison with the above, the record of a root of Vicia Faba very similarly handled is given in Table X. Total length of root, $22 \mathrm{~mm}$. Temperature, $20 \cdot 0^{\circ}-23 \cdot 0^{\circ} \mathrm{C}$.

The contraction following the transfer to the solution of $\mathrm{KNO}_{3}$ is here plainly marked. Indeed, it has an approxi-

E e 


\section{True.-On the Influence of Sudden Changes of}

mately average magnitude, and in the manner of its occurrence is quite typical. In order to show more exactly the timerelations involved, measurements taken at short intervals during the first half-hour after the transfer to the salt-solution are shown in Table XI.

The contraction is seen to begin immediately, and to be

TABLE XI.

\begin{tabular}{|c|c|c|c|}
\hline Period. & \multicolumn{2}{|c|}{ Change in length. } & Medium. \\
\hline $2.30-2.33$ & -8.0 uni & scale & $\mathrm{I} \% \mathrm{KNO}_{3}$ \\
\hline $2.33-2.36$ & $-\mathrm{I} \cdot \mathrm{O}$, & ", & " \\
\hline $2 \cdot 3^{6-2 \cdot 40}$ & $-\mathrm{I} \cdot \mathrm{O} \quad$, & ", & " \\
\hline $2.40-2.45$ & -0.5, & $"$ & ", \\
\hline $2.45^{-2.50}$ & 0.0 & " & , \\
\hline $2.50 \cdots 2.55$ & I.O , , & , & , \\
\hline $2.55^{-3}$ & $2.0 \quad$, & ," & ", \\
\hline
\end{tabular}

I unit of scale $=0.0182 \mathrm{~mm}$.

finished very soon. After a short period of equilibrium, growth begins at a slow rate, but fails to recover the normal speed before the change to water takes place. The return of the radicle to water is followed by the usual elastic elongation. In the following table, the time-relations are shown more in detail.

TABLE XII.

\begin{tabular}{|c|c|c|c|c|}
\hline Period. & \multicolumn{3}{|c|}{ Growth. } & Medium. \\
\hline $6.30-6.35$ & \multicolumn{3}{|c|}{ I0.0 units of scale } & Water \\
\hline $6.35^{-6.40}$ & $6 \cdot 0$ & , & , & " \\
\hline $6.40-6.45$ & $4 \cdot 0$ & , & , & " \\
\hline $6.45^{-6.50}$ & $2 \cdot 0$ & , & " & , \\
\hline $6.50-6.55$ & $I \cdot 5$ & " & ", & $"$ \\
\hline $6.55^{-7}$ & $\mathrm{I} \cdot 5$ & ", & , & " \\
\hline
\end{tabular}

I unit of scale $=0.0182 \mathrm{~mm}$.

The elastic elongation takes place very soon after the change to water, and is of short duration. 
The study of these elastic changes of length was made under differing conditions, and the essential features were found not to vary from the foregoing. The contraction observed to accompany the transfer to the $\mathrm{KNO}_{3}$ solution was always of less magnitude than the elongation seen to follow the return to water.

It must not be forgotten that in each case we have to do with more than a simple turgor-change. The growth prevailing at the time of such change of medium enters as a complicating factor. If we transfer a root from water to a saltpetre solution, we cannot regard the growth-rate as instantaneously adjusting itself to the new medium. The former speed gives a certain impulse that must be overcome before the new conditions can produce their characteristic effect. It will still operate for a short time in the new medium. We would not expect, therefore, the entire work resulting from the change of turgor to find expression in the altered length of the root, a part being expended in working against the prevailing impetus of growth. We see as a contraction only the resultant of the two factors, the larger of which is the elastic change due to turgor.

In the case of the transfer from the saltpetre solution to water, we have the same two factors present, but here they work in the same direction, and the alteration in length is equal to the sum of the two factors. The contraction is the sudden halt called forth by the substratum, the elastic elongation is the push given by it. To resolve the resultants above found into their numerical components is here not attempted.

As may be seen in the experiments above detailed, a transfer from water to a saltpetre solution is followed by a more or less prolonged period of retarded growth ${ }^{1}$. A reduced growth-rate is likewise seen to follow very regularly the reverse change of medium, although a quite rapid rate of growth may prevail in the $\mathrm{KNO}_{3}$ solution immediately prior to the transfer to water. Thus a depression of growth

1 In Tables II to VII, all radicles were placed in water and allowed to assume a normal growth-rate before being brought into the $\mathrm{KNO}_{3}$ solution.

E e 2 


\section{True.-On the Influence of Sudden Changes of}

is the result of a change of medium as well when this change calls forth an increased, as when it calls forth a decreased turgor-pressure. The conclusion follows that here the rate of growth stands in no direct proportion to the turgor-pressure. This is in accordance with the fact lately demonstrated by Pfeffer ${ }^{1}$, that turgor is not necessary for the growth of the cellmembrane.

To point out the causes of this is no simple task. For greater clearness, let us consider the two cases separately.

In the case of a change from a saltpetre solution to water, it is plainly impossible that the diminished growth-rate should have for its cause a lack of turgor-pressure. Abundant evidence from other sources shows that a reduced growth-rate can accompany an increasing turgor-pressure. Wieler ${ }^{2}$, Stange ${ }^{3}$, and Eschenhagen ${ }^{4}$ may be cited in this connexion. Hegler ${ }^{5}$ found that a mechanical pull in the direction of the long axis of a plant caused a diminished rate of growth and an increased turgor.

It seems that we have here a plain exhibition of protoplasmic irritability. The change of concentration acts as a stimulus, which calls forth a reaction in the form of a diminished rate of growth.

A number of possible causes of the diminished growth-rate succecding the sudden change from water to the salt-solution suggest themselves.

(I) Perhaps the return of full growth is delayed until a. necessary minimum turgor-pressure is established. The period of retarded growth, as seen in roots of Vicia Faba, suddenly brought into a I per cent. solution of $\mathrm{KNO}_{3}$, lasts usually from $2 \frac{1}{2}$ to $3^{\frac{1}{2}}$ hours. Whether such a period is necessary for the turgor-adjustment does not appear, the time relations of this change not having received especial attention

1 Pfeffer, Druck u. Arbeitsleistung, p. 429.

${ }^{2}$ Wieler, Plasmolytische Versuche mit unverlutzten Phanerogamen, Ber. d. deutsch. bot. Gesellsch. I887, p. 375 .

${ }^{3}$ Stange, loc. cit.

${ }^{4}$ Eschenhagen, loc. cit.

${ }^{5}$ R. Hegler, Ueber den Einfluss des mechanischen Zuges auf das Wachsthum der Pflanzen. Cohn's Beitr. z. Biol. d. Pflz., Bd. VI, Heft 3, p. I. 


\section{Turgor and of Temperature on Growth. 385}

as yet. The few experiments bearing on this point give a very incomplete view of details. De Vries ${ }^{1}$ states that out of 0.35 molecules of glycerine, 0.03 pass into the cell in one hour. Janse ${ }^{2}$ found plasmolyzing substances in the cell-sap of Spirogyra after 30 minutes in either dilute or concentrated solutions. Eschenhagen ${ }^{3}$ found that the hyphae of moulds, transferred suddenly from a 10 per cent. to a 40 per cent. sugar-solution, after 6 hours were plasmolyzed by a 30 per cent. sugar-solution, not yet having reached the concentration of the new medium. It is here to be noticed, however, that the increase in osmotically active substances is brought about, not by penetration of the sugar, but by metabolic activity in the cells themselves, and a different action may result.

It seems entirely possible in the case under consideration that an interval equal to the retardation-period found, might be necessary for an adjustment of the turgor-pressure. If this should be the case, it would not be unexpected were the rate of growth during this period to show more or less disturbance.

(2) In view of the exhibition of irritation seen to follow the reverse change of medium, it would seem highly probable that here a similar phenomenon might be present.

(3) It seems possible that the medium may exert a specific chemical effect on the seedlings placed in it. Evidence supporting such a supposition is afforded only by roots that were left in the saltpetre solution for long periods of time.

\section{Recapitulation.}

Bringing together the most important results following from the experiments above presented, it appears (I) that a sudden and decided increase of the concentration of the liquid medium calls forth in growing roots a change of turgor-pressure, producing, or tending to produce, a mechanical contraction, also

1 De Vries, cited by Stange, loc. cit.

2 Janse, Plasmolytische Versuche an Algen, Bot. Centraibl. XXXII (188 7 ), Th. i, p. 2 I.

${ }^{3}$ Eschenhagen. loc. cit., p. 35 . 


\section{True.-On the Influence of Sudden Changes of}

a more or less prolonged period of retardation of the growthrate. The cause of the retardation was not demonstrated, but is probably due, in part, to decrease of the turgor-pressure, and, in part, to a sensitive reaction following the irritation of the living organisms.

(2) A sudden and decided decrease of the concentration of the medium causes a change of turgor-pressure producing. a mechanical elongation, also a more or less prolonged period of retardation of growth. The cause of the retardation is found in a sensitive reaction of the living organisms to the change of medium. Since a reduction of growth is found to accompany both an increase and a decrease of turgor-pressure, it follows that growth and turgor-pressure here stand in no directly proportional relation to each other.

\section{The Effect of Sudden Changes of Temperature.}

\section{Historical.}

Although a number of earlier investigators ${ }^{1}$ had studied the effects of sudden temperature changes on the streaming of protoplasm, Koeppen ${ }^{2}$ first investigated the effect exerted on plant-growth. He concluded that the act of change brought about a reduction of growth in radicles of various seedlings.

Sachs ${ }^{3}$, from observations on the growth of certain etiolated stems, was unable to confirm this view.

Pedersen's ${ }^{4}$ results led him also to take exception to Koeppen's generalization. He exposed roots of seedlings of

${ }^{1}$ Max Schultze, Protoplasma der Rhizopoden und der Pflanzenzelle, I863, p. 63. Dutrochet, Comptes Rendus, I837, T. V, p. 777 ff. Hofmeister, Pflanzenzelle, 1867 , pp. 47 and 53. See also Sachs, Handbuch der ExperimentalPhysiologie der Pflanzen, 1865 , p. 69.

${ }^{2}$ Koeppen, Wärme und Pflanzenwachsthum. Dissertation, Moskau, I87o, pp. 20 and 22.

3 Sachs, Ueber den Einfluss der Lufttemperatur und des Tageslichts auf die stïndlichen und täglichen Änderungen des Langenwachsthums der Internodien. Arb. d. bot. Inst. in Würzburg, I872, Heft II, p. 164. Also, Gesammelte Abhandlungen über Pflanzenphysiologie, Bd. II, p. 677.

${ }^{4}$ Pedersen, Haben Temperaturschwankungen einen ungünstigen Einfluss auf das Wachsthum? Arb. d. bot. Inst. in Würzburg, Bd. I (I874), p. $5^{6} 3$. 
Vicia Faba to both sudden and to gradual changes of temperature between $10^{\circ}$ and $20^{\circ} \mathrm{R}$., and found the growth-rate to depend solely on the absolute temperature, the act of change being entirely without influence.

Askenasy $^{1}$, with a more accurate method of measurement, found that the influence due to a sudden change of temperature depended on the position of the lower limit. When the minimum temperature used still permitted growth, the change to the higher degree was followed by an immediate assumption of the rate of growth characteristic for the new temperature. When, however, the minimum temperature was near the zero point, the transfer to the higher temperature was followed by a more or less tardy assumption of the normal growth-rate. Pfeffer ${ }^{2}$ noted a similar gradual return of growth after roots which had been in a temperature of $0.5^{\circ} \mathrm{C}$. for 12 hours were brought into a warmer medium.

Godlewski ${ }^{3}$ saw very similar results in the case of epicotyls of Phaseolus vulgaris, when they were exposed to sudden changes of the temperature of the surrounding air. Whether the temperature was raised or lowered, a temporary decrease of growth-rate followed.

Pfeffer ${ }^{4}$ found that changes of temperature caused the opening and closing of flowers of Crocus and of Tulipa by bringing about unequal growth in antagonistic parts of the perianth-members. A rising temperature caused a more rapid growth of the upper part, and opening followed; a falling temperature, on the other hand, caused a more rapid growth of the under part, and thus the closing of the flower. The same author ${ }^{5}$ observed that changes of temperature act as

1 Askenasy, Ueber einige Beziehungen zwischen Wachsthum und Temperatur. Ber. d. deutsch. bot. Gesellsch., Bd. VIII (I890), p. 75 .

${ }^{2}$ Pfeffer, Druck und Arbeitsleistung durch wachsende Pflanzen. Abh. d. Königl. Sächs. Gesellsch. f. Wissensch., Bd. XX, Heft III, pp. 893, 354 .

${ }^{3}$ Godlewski, Ueber die Beeinflussung des Wachsthums der Pflanzen durch äussere Faktoren. Anz. d. Akad. d. Wissensch. in Krakau, I890, p. I66.

${ }^{4}$ Pfeffer, Physiologische Untersuchungen. Leipzig, 1873, p. 194.

${ }^{5}$ Pfeffer, Die periodischen Bewegungen der Blattorgane. Leipzig, 1875, p. 135 . 


\section{True.-On the Influence of Sudden Changes of}

weak stimuli in inducing leaf-movements of Oxalis Acetosella and of Mimosa pudica ${ }^{1}$.

\section{Materials and Methods.}

As far as here applicable, the materials and methods used were like those already described in the first part of this paper. Radicles of the same species were germinated in the same manner. Measurements were made with the scale and the horizontal microscope. Owing to the liability of disturbance by the expansion and contraction of parts of the apparatus, the measurements with the horizontal microscope were usually made from point to point. The results thus obtained differed, however, but very slightly from those yielded by the measurement of the movement of the tip on the ocular micrometer.

To obtain the desired temperatures, resort was had to a number of devices. As the experiments demanding low temperatures were made in winter, it was found easy, by the use of a cold room and ice, to obtain the desired result. The higher temperatures were found in rooms provided with automatic heat-regulators. For the limited time occupied by the experiments involving the use of the horizontal microscope, it was found practicable, with a room-temperature of $19^{\circ} \mathrm{C}$. to obtain the desired temperatures by the use of a microburner or of small pieces of ice added at regular intervals.

Because of the obvious advantages, experiments were usually made with roots in water. Comparison experiments were made in sawdust.

\section{Experimental.}

In order to gain a general view of the effects accompanying extreme changes, several series of roots of Vicia Faba were exposed to a temperature near the zero point for various periods of time, and were then suddenly brought into a temperature of about $24^{\circ} \mathrm{C}$.

Four roots of Vicia Faba seedlings were exposed for 220 hours to a temperature varying between 0.40 and $2.5^{\circ} \mathrm{C}$,

${ }^{1}$ Pfeffer, Pflanzenphysiologie, I88I, Bd. II, p. ${ }^{2} 3$ I. 
making during this time an average growth of $0.7 \mathrm{~mm}$. per 24 hours. They were quickly transferred to a temperature of $23^{\circ} \mathrm{C}$, and the further growth measured at suitable intervals. As one showed abnormal symptoms, the following table shows averages drawn from but three specimens.

The feature here to be noted is the long period of retarded growth following the change to the higher temperature. The roots seem during the exposure to the cold to have gone into

TABLE XIII.

\begin{tabular}{|c|c|c|c|}
\hline \multicolumn{2}{|c|}{ Period. } & Growth per hr. & Temperature. \\
\hline Hours. & Min. & & \\
\hline 3 & 30 & $0.28 \mathrm{~mm}$ & $24 \cdot 2^{\circ} \mathrm{C}$. \\
\hline 2 & 45 & $0.24 "$ & 23.6, \\
\hline I 6 & 45 & $0.27 "$ & $22 \cdot 4$, \\
\hline 24 & $\infty$ & $0.03 "$ & 23.5, \\
\hline 23 & 30 & 0.37, & $23 \cdot 6$, \\
\hline 24 & 30 & I.06 " & $23 \cdot 6$, \\
\hline 24 & $\infty$ & $0.90 "$ & $23.9 "$ \\
\hline 48 & 30 & 0.69, & $23 \cdot 8$, \\
\hline 24 & $\infty$ & 0.60, & $23 \cdot 8$, \\
\hline 23 & 30 & 0.37, & 23.9, \\
\hline
\end{tabular}

a state of torpor, from which an awakening to full activity takes place but slowly. The course of the growth-curve seems to be permanently affected. The maximum lies lower than is normally the case in this temperature, and the descending limb falls more abruptly than in the normal curve. Unless a correlative change, giving a longer-growth period than usual, takes place, the total growth here suffers a diminution.

Table XIV gives the average growth-rates of four roots of Vicia Faba during and after a stay of 48 hours in a temperature varying between $2.5^{\circ}$ and $6.0^{\circ} \mathrm{C}$.

The period of retarded growth here seen to follow the temperature-change is very much less marked than in Table XIII. 


\section{True.-On the Influence of Sudden Changes of}

Although the lower temperature limit is here somewhat higher, it can hardly be regarded as accounting for the speedy return of the normal growth-rate, since a parallel experiment with

TABLE XIV.

\begin{tabular}{|c|c|c|c|}
\hline \multicolumn{2}{|c|}{ Period. } & Growth per hr. & Temperature. \\
\hline $\begin{array}{c}\text { Hours. } \\
\text { I }\end{array}$ & $\underset{\infty}{M i n}$ & $0.00 \mathrm{~mm}$ & $2.5^{\circ} \mathrm{C}$ \\
\hline 7 & ০০ & $0.00 \quad "$ & $3 \cdot 2$, \\
\hline 17 & ০০ & $0.05 \quad$, & 6.0, \\
\hline 23 & ০০ & 0.07, & $4 \cdot 8$, \\
\hline 2 & ০০ & 0.40, & 19.2, \\
\hline $2 \mathrm{I}$ & ০০ & $0.6_{5}$, & I 8.0, \\
\hline 23 & ০০ & $0.75 \quad$ & I 8.5, \\
\hline
\end{tabular}

the lower limit between $0.4^{\circ}$ and $0.6^{\circ} \mathrm{C}$. gives no longer period of retardation.

In Table $\mathrm{XV}$ are given the average growth-rates drawn

TABLE $X V$ 。

\begin{tabular}{|c|c|c|c|}
\hline \multicolumn{2}{|c|}{ Period. } & \multirow{2}{*}{$\begin{array}{c}\text { Growth per hr. } \\
0.25 \mathrm{~mm} .\end{array}$} & \multirow{2}{*}{$\begin{array}{c}\text { Temperature. } \\
6.0^{\circ} \mathrm{C} .\end{array}$} \\
\hline $\begin{array}{c}\text { Hours. } \\
2\end{array}$ & $\begin{array}{c}\text { Min. } \\
\text { O० }\end{array}$ & & \\
\hline I 5 & 45 & $0.02 "$ & $2 \cdot 0$, \\
\hline I & 30 & $0.50 "$ & $22 \cdot 4$, \\
\hline 2 & 45 & $\mathrm{I} \cdot 22 \Longrightarrow$ & $23 \cdot 0$, \\
\hline 3 & $\infty$ & 1.08, & 23.0, \\
\hline 20 & I5 & I.I 6 & $23 \cdot 0$, \\
\hline $2 \mathrm{I}$ & $\infty$ & I.06 , & $22.5 \%$ \\
\hline
\end{tabular}

from four roots of Vicia Faba during and after a stay of about 18 hours in a low temperature.

Here a slight retardation is seen, which is quickly superseded by a fully normal growth-rate.

It was found in further experiments here not detailed, that 
by shortening the period of exposure to the low temperature, the change to the higher degree was followed by no retardation that could be detected by measurements with the scale; the normal growth seemed to be immediately assumed.

It was noticed in comparative experiments with roots cultivated in sawdust, that a somewhat longer period of exposure to the cold was necessary in order to produce a retardation than in cultures in water. A recovery of the normal growth took place more rapidly in the former case.

In order to study more accurately the results following temperature-changes, the horizontal microscope was again brought into use. Plainly this method of measurement is suited only to experiments occupying shorter periods of time,

TABLE XVI.

\begin{tabular}{|c|c|c|}
\hline Period. & Growth in scale units. & Temperature. \\
\hline $10.10-10.40$ & I6.o units & $18.5^{\circ} \mathrm{C}$. \\
\hline $10.40-\mathrm{J} 1.10$ & 5.0, & I8.6, , \\
\hline I I.IO-1 I.40 & 2.0, & I $8 \cdot 7$, \\
\hline II.40-3.10 & 2.0 units per $\frac{1}{2} \mathrm{hr}$. & 18.8-19.7, , \\
\hline $3.10-3 \cdot 40$ & $3.0 \quad$, & I9.7, \\
\hline $3 \cdot 40-4 \cdot 10$ & $2.5 "$ & $19 \cdot 8$, \\
\hline $4 \cdot 10-4 \cdot 40$ & $2 \cdot 5 \quad$ & 19.8, \\
\hline $4 \cdot 4^{0-6.10}$ & 2.0, & $19.8-20 \cdot 0$, \\
\hline
\end{tabular}

I unit $=0.0182 \mathrm{~mm}$.

and is, therefore, not well adapted to the study of long-continued reactions following prolonged exposure to low temperatures. Only those phenomena which occur soon after a change can be here most profitably followed. When the exposure to low temperatures is short, and the normal growth soon returns, this instrument is also called into use.

Before passing to the latter class of experiments, we will briefly notice the results seen to immediately follow the return to a higher temperature after a prolonged exposure to cold.

In Table XVI is shown the record of a Vicia Faba radicle 


\section{True.-On the Influence of Sudden Changes of}

following the transfer from $0.5^{\circ}-2 \cdot 0^{\circ} \mathrm{C}$, to $18.5^{\circ}-19.8^{\circ} \mathrm{C}$. The time spent in the lower temperature was 94 hours.

The striking feature of this experiment is the slight elongation occurring promptly after the change, and the subsequent rapid fall of the curve.

A measurement made at II.25, I 5 minutes after the transfer from the cold, showed that i I of the 16 units of elongation were made during the first quarter of an hour. That this is in part due to a turgor-change will appear from further considerations.

Table XVII gives the increments of elongation shown by measurements made every I 5 minutes seen in a root of Pisum sativum under very similar circumstances. The root was exposed 48 hours to a temperature of $0.5^{-0} \cdot 8^{\circ} \mathrm{C}$., and was then suddenly brought into a temperature of $19.4^{\circ} \mathrm{C}$.

TABLE XVII.

\begin{tabular}{|c|c|c|}
\hline Period. & Growth in scale units. & Temperature. \\
\hline I I.30-I I. 45 & I9.0 units & $19.5^{\circ} \mathrm{C}$. \\
\hline I I. $45^{-1} 2$ & $5.0 \quad$, & $19 \cdot 6$, \\
\hline I $2-\mathrm{I} 2 \cdot \mathrm{I} 5$ & $4.0,$, & 19.6, \\
\hline I $2.15^{-12.30}$ & $4.0 \quad$, & I9.6, \\
\hline
\end{tabular}

I unit $=0.0182 \mathrm{~mm}$.

Essentially the same result is here repeated. A fuller consideration of this phenomenon is reserved for another place.

A number of experiments were made to ascertain the effect of a short exposure to a low temperature. To this end the growth-rate at the room-temperature was first obtained, then the radicle was transferred to a low temperature, and the growth was observed for a given time. The transfer to the original temperature was then made, and the further growth noted.

In Table XVIII is shown the record made by a root of Vicia Faba observed before, during and after an exposure for two hours to a temperature of $1 \cdot 2^{\circ}$ to $2 \cdot 0^{\circ} \mathrm{C}$. 
Turgor and of Temperature on Growth. 393

The transfer to the lower temperature causes not merely a sudden checking of the growth, but, in fact, a slight contraction. In this case measurements at shorter intervals

TABLE XVIII.

\begin{tabular}{|c|c|c|}
\hline Period. & - Growth. & Temperature. \\
\hline I $2.55^{-I .25}$ & I 6.0 units & $18.9^{\circ} \mathrm{C}$. \\
\hline I. $25^{-\mathrm{I}} .55$ & I $7.0 \%$ & 19.0, \\
\hline I. $55^{-2.25}$ & $\mathrm{I} 4.0 \%$ & 19.0, \\
\hline $2.25^{-2.55}$ & $-\mathrm{I} \cdot \mathrm{O}$, & I. 8, \\
\hline $2.55-3.25$ & $\mathrm{I} \cdot 5 \quad$, & I.6, \\
\hline $3.25-3.55$ & 0.5, & I.4 \\
\hline $3.55-4.25$ & I.0 , , & I.2, \\
\hline $4.25-4.55$ & 10.0, & I9.3, \\
\hline $4.55^{-5.25}$ & II.5 & 19.6, \\
\hline $5.25-5.55$ & $10.0 "$ & I9.7 , \\
\hline
\end{tabular}

I unit $=0.0182 \mathrm{~mm}$.

brought out the fact that the contraction took place during the first five minutes after the temperature-change, the growth during the remainder of the half-hour being at a complete standstill. It then begins at a very slow rate and continues

TABLE XIX.

\begin{tabular}{|c|c|c|}
\hline Period. & Growth. & Temperature. \\
\hline $2 \cdot 35-3 \cdot 5$ & II $\cdot 5$ units & $20.0^{\circ} \mathrm{C}$. \\
\hline $3 \cdot 5^{-3.35}$ & -I.O , , & $0.7 "$ \\
\hline $3 \cdot 35-4.5$ & $-2 \cdot 5$ & 0.8, \\
\hline $4 \cdot 5^{-4.35}$ & 5.5, & 20.4, \\
\hline $4 \cdot 35-5 \cdot 5$ & $7.5 \%$ & 20.4, \\
\hline $5 \cdot 5-5 \cdot 35$ & 12.0 & $20.5 \%$ \\
\hline
\end{tabular}

I unit $=0.0182 \mathrm{~mm}$.

rather irregularly until the change to the higher temperature takes place. This change is marked by the immediate assumption of a rate of elongation that is maintained with little change 


\section{True.-On the Influence of Sudden Changes of}

during the remainder of the experiment. This rate, however, is but about two-thirds as great as that seen in this temperature at the beginning of the experiment.

For comparison with the above is given in Table XIX the result of a somewhat similar experiment with a root of Pisum sativum.

The prolonged contraction here following the transfer to the lower temperature was seldom seen. The return of the normal growth here takes place in a gradual manner.

In Table XX is shown the record made by a radicle of Lupinus albus exposed for 30 minutes to a temperature of $0.5^{\circ} \mathrm{C}$.

TABLE XX.

\begin{tabular}{|c|c|c|}
\hline Period. & Growth. & Temperature. \\
\hline $3 \cdot 30-4$ & I I. 5 units & $19 \cdot 2^{\circ} \mathrm{C}$. \\
\hline $4-4 \cdot 30$ & $-0.5 \%$ & 0.5, \\
\hline $4 \cdot 30-5$ & I I.5 & I9.3, \\
\hline $5-5 \cdot 30$ & I0.0 , , & 20.0, \\
\hline
\end{tabular}

I unit $=0.0182 \mathrm{~mm}$.

The rate of elongation following the return to the usual temperature is equal to the growth-rate prevailing before the exposure.

In the experiments thus far considered, we find that a minimum period of exposure to a low temperature exists, following which no reaction can be detected with the scale; we find also in experiments involving microscopic measurements that the retardation or reaction may be reduced by decreasing the period of exposure to the low temperature. A certain duration of the application of the stimulus is necessary to call forth a plain reaction.

In the preceding experiments, the lower temperature limit was near the minimum for growth. Those following deal with the effects arising from changes between limits that are plainly useful for plant-growth. 
Turgor and of Temperature on Growth. 395

No experiments involving measurements with the scale were made, since, from the foregoing, it would seem highly improbable that the stimulus given would produce a reaction sufficiently great to be detected by this means.

The experiments of Pedersen ${ }^{1}$ tend to confirm this view. Roots of Vicia Faba exposed to sudden and to gradual changes of temperature between $10^{\circ}$ and $20^{\circ} \mathrm{R}$. gave no evidence of any retardation of growth that could be detected with the scale.

TABLE XXI.

\begin{tabular}{|c|c|c|}
\hline Period. & Growth per $\frac{1}{4} \mathrm{hr}$. & Temperature. \\
\hline $10.25-$ II .25 & 2.8 units & $30 \cdot 0-30 \cdot 2^{\circ} \mathrm{C}$ \\
\hline II. $25^{-1}$ I. $4^{\circ}$ & $4.5 \quad$ & 30.I $\quad$, \\
\hline I I. 40 -I I. 55 & 3.0, & $30.0 \quad$ \\
\hline II. $55^{-I} 2.10$ & $1.5 \%$ & 18.0 \\
\hline I $2.10-12.25$ & I.0 , & I $8 . \mathrm{I}$, \\
\hline I $2.25^{-2.25}$ & 2.I , , & I $7 \cdot 9-18 \cdot 2$, \\
\hline $2.25^{-2.40}$ & I.5 , & I $8.2 \quad$, \\
\hline $2.40-2.55$ & $2.5 \quad$ & I 8.2, \\
\hline $2.55^{-3.10}$ & 6.0, & $30 \cdot 2 \quad$ \\
\hline $3.10-3.25$ & $4.5 \quad$ & $30 \cdot 2-30 \cdot 0$, \\
\hline $3.25-3.55$ & $4.0 \quad$ & $30.0 \quad$ \\
\hline $3.55-4.10$ & $5 \cdot 5 \quad$, & $30 \cdot 0$ \\
\hline $4.10-4.25$ & I. $5 \%$ & I 8.2, \\
\hline $4.25-4 \cdot 4^{\circ}$ & $3.0 \quad$, & I 8.0 \\
\hline $4.40-4.55$ & $2.0 \quad$ & 18.0 \\
\hline
\end{tabular}

I unit $=0.0429 \mathrm{~mm}$.

An attempt to secure the simple effect of temperature-change, as such, was made in the following manner. By reference to a table ${ }^{2}$ of growth-rates at various temperatures, two points were selected, one above the optimum and one below it, at which the growth-rates were approximately equal. As such for Vicia Faba $\mathrm{I} 8^{\circ}$ and $30^{\circ} \mathrm{C}$. were selected. On transferring

${ }^{1}$ Pedersen, loc. cit.

${ }^{2}$ Koeppen. loc. cit., p. 40. Also Pfeffer, Pflanzenphysiologie, Bd. II, p. I 29. 


\section{True.-On the Influence of Sudden Changes of}

a radicle from one of these temperatures to the other, the growth-rate at both being assumed to be the same, any change regularly accompanying such transfer would be regarded as referable to this change for its cause. It would be expected a priori that such growth-changes would be slight and possibly less conspicuous than those due to internal stimuli. It is well known that normal growth from time to time makes very considerable changes of rate. Hence, as in this experiment, where the factors are so nearly balanced, the one evidence that a given change in the rate of growth is due to the

TABLE XXII.

\begin{tabular}{|c|c|c|}
\hline Period. & Growth per $\frac{1}{4} \mathrm{hr}$. & Temperature. \\
\hline I $0.30-$ I I.30 & I.O units & I $7 \cdot 9-18.2^{\circ} \mathrm{C}$ \\
\hline I I.30-I I. 45 & I.O & $\mathrm{I} 8 \cdot 2^{\circ} \mathrm{C}$. \\
\hline I I. $45^{-1} 2$ & 0.5, & I 8.0, \\
\hline I 2-I 2.15 & $2 \cdot 5$, & 30.0, \\
\hline I $2.15-12.30$ & I.O, , & 30.2, \\
\hline I $2.30-2.30$ & $2 \cdot 7$ & $29.9-30.1$, \\
\hline $2.30-2.45$ & $2 \cdot 5 \quad$ & 30.0, \\
\hline $2.45^{-3}$ & $\mathrm{I} \cdot 5, \mathrm{,}$ & I 8.2, \\
\hline $3-3.15$ & $2.5 \quad$, & I 8.2, \\
\hline $3.15-3.45$ & I. 8, & I 8.3, \\
\hline
\end{tabular}

I unit $=0.0429 \mathrm{~mm}$.

temperature-change, is the constancy with which the variation of temperature is accompanied by the change of growth-rate. This, however, may not always apply, especially when internal, spontaneous stimuli act in opposition. The growth-rate then seen would indicate the resultant.

Under the conditions above described, a root of Vicia Faba about $30.0 \mathrm{~mm}$. long made the record shown in Table XXI.

Table XXII gives the record of a similar experiment with a root of Vicia Faba.

Inspection of Tables XXI and XXII shows that every change from $30^{\circ}$ to $18^{\circ}$ is followed by a reduction of the growth-rate 
during the ensuing quarter hour. Further effects plainly due to the change are not to be traced in the later growth. It increases or diminishes according to the internal conditions prevailing. The transfer from $18^{\circ}$ to $30^{\circ}$ is always followed by an increased amount of elongation during the ensuing I 5 minutes. As before, the growth-rate gives no further evidence of being influenced by the temperature-change. In both cases, the traceable effects of the change disappear within I 5 minutes.

By subtracting the growth made during the period following a temperature-change from that made during the period preceding the change, we get the amount of retardation or of elongation due to the change. To be sure, an uncertain factor in every case is the possible change in the rate of growth due to internal stimuli, and the results obtained can perhaps hardly be regarded as the pure effect of the act of temperaturechange. This source of error is, however, not to be avoided. The amount of retardation so calculated, following the sudden transfer from $30^{\circ}$ to $18^{\circ}$, is rather variable, as would, indeed, be expected, and depends somewhat on the rate of growth prevailing at the time of the change. The average retardation calculated from a number of experiments is $0.08 \mathrm{~mm}$. The growth during the following period is usually equal to the average found at the temperature in question. On making the reverse change, the acceleration of the rate of elongation called forth during the period following is likewise rather variable, but averages $0.1 \mathrm{Imm}$. Here again the succeeding growth is usually characteristic for the higher temperature. In both cases the growth-rate of the new temperature seems to be immediately assumed. This receives further attention below.

The phenomena of contraction and of elongation seen immediately after a sudden temperature-change between extremes more widely separated, as well also as the succeeding retardation of the growth, seem to call for a closer examination.

- A sudden fall of temperature, as we have seen, produces F f 


\section{True.-On the Influence of Sudden Changes of}

under different circumstances apparently different results. If the lower extreme be near the zero point, and the intervening number of degrees be sufficient ( $18^{\circ} \mathrm{C}$. usually in the above experiments), a shortening of the radicle is generally seen to take place within five minutes. If the lower extreme, however, be at a medium temperature $\left(\mathrm{I} 8^{\circ}\right)$ and the fall of temperature be but $12^{\circ} \mathrm{C}$., no such shortening is seen. Instead, however, an immediate retardation of growth invariably takes place. A change in the reverse direction gives an immediate elongation or an increased rate of apparent growth. Roughly speaking, the greater the number of degrees of temperature increase, the greater is the elongation. This statement is made only for temperatures used in these experiments.

That the location of the minimum point, as such, has no decided influence, is shown by a computation from the averages drawn from the above experiments, and from others not detailed in this paper. The average elongation in the first fifteen minutes following the transfer from 0.40 to $19.0^{\circ} \mathrm{C}$. is found to be $0.18 \mathrm{~mm}$. or $0.0 \mathrm{I} \mathrm{mm}$. per degree. The corresponding elongation following the transfer from $18.0^{\circ} \mathrm{C}$. to $30^{\circ} \mathrm{C}$. is $0.095 \mathrm{~mm}$. or $0.009 \mathrm{~mm}$. per degree. The elongation was obtained by subtracting the number of units of growth made during the fifteen minutes' period preceding the transfer, from the number of units of apparent growth made during the like period following the change. The absolute elongation due to the change of temperature seems, therefore, within the limits here given, to vary according to the number of degrees intervening.

Whether the maximum-temperature limit, as such, has any peculiar influence, does not appear from experiments here made. There seems to be no reason to expect such.

With these conclusions may be compared the results of G. Kraus' ${ }^{1}$ experiments on tissues of internodes. Judging from the elongation and the contraction of isolated tissues, he found the tensions to change but slightly by variations of

1 G. Kraus, Bot. Zeit. 1867 , p. I24. Compare also Pfeffer, Zur Kenntniss der Plasmahaut und der Vacuolen, \&cc. Leipzig, 189o, p. 309 (163). 
temperature between $14^{\circ}$ and $38^{\circ} \mathrm{C}$., whereas a considerable decrease occurred by a reduction below $7^{\circ}$ or $8^{\circ} \mathrm{C}$.

What causes produce these promptly occurring but quickly passing changes?

A number of possible factors suggest themselves.

First, the root as a mass of matter contracts or expands when exposed to changes of temperature in a manner entirely analogous to the changes in length of an iron rod when heated or cooled. Determinations of the coefficient of expansion of tissues like those here concerned seem to be lacking, but judging from those made from wood ${ }^{1}$, this factor is so small as to certainly fall within the range of error, and can be entirely neglected.

Second, changes of temperature cause changes of turgorpressure. From experiments made by $\mathrm{Pfeffer}^{2}$, it has been shown ${ }^{3}$ that turgor-pressure is influenced by temperaturechanges in the same manner as gas-pressure. That is, the osmotic pressure increases proportionally to the absolute temperature.

Taking as the coefficient of expansion per degree centigrade 0.00367 , or approximately $\frac{1}{2} \frac{1}{3}$, a turgor-pressure of 100 by a temperature increase of $10^{\circ} \mathrm{C}$. becomes $103.67^{4}$. If normal roots of Vicia Faba $20 \mathrm{~mm}$. in length be deprived of turgor-pressure ${ }^{5}$ by the action for 30 minutes of a 3 per cent. $\mathrm{KNO}_{3}$ solution, an average contraction of about $2.0 \mathrm{~mm}$. (drawn from 8 specimens) takes place. If similar radicles be exposed to a sudden change of temperature from $19^{\circ}$ to $\mathrm{I}^{\circ} \mathrm{C}$. the turgor-reduction would theoretically be $\frac{36}{273} \mathrm{~mm}$. or 0.132 $\mathrm{mm}$. The average contraction actually found under these conditions was $0.035 \mathrm{~mm}$. It is thus plain that the turgorchanges due to temperature variations are of sufficient

${ }^{1}$ Villari, Annal. d. Physik u. Chemie, Bd. CXXXIII (I868), pp. 4I 2, 4I7. Pfeffer, Pflanzenphysiologie, Bd. II, p. 4I.

${ }^{2}$ Pfeffer, Osmotische Untersuchungen, I877, p. 83 .

${ }^{3}$ Van't Hoff, Zeitschr. f. physik. Chemie, Bd. I (I887), p. 486.

${ }^{4}$ Pfeffer, Zur Kenntniss der Plasmahaut u. Vacuolen, \&c. Abh. d. Königl. Sächs. Gesellsch. d. Wissensch., Bd. XVI (I 890), Heft II, p. 308.

${ }_{5}^{5}$ Pfeffer, Druck u. Arbeitsleistung, p. 297. 


\section{True.-On the Influence of Sudden Changes of}

magnitude to fully account for the transitory changes of length under consideration.

That the change of turgor-pressure finds in the radicle observed an unmodified expression is hardly to be expected. The conditions of growth prevailing at the time of a change of temperature seem to modify the extent of the elongation and of the contraction, or, in case no contraction is seen, of the following growth-rate, in much the same way as is noted above (p. $3^{83}$ ). The resolution of the resultants into their factors is a problem hardly soluble from the data at hand.

That the sudden temperature-changes may act as stimuli which release growth influencing factors seems not unlikely. If such factors enter, their magnitude is a matter of uncertainty. It seems, in view of these possibilities, justified to regard the changes of length under discussion as due to variations of turgor-pressure modified to a greater or less extent by factors having their origin in the organisms.

It remains to notice the period of depression of growth seen to follow changes of temperature. As has been pointed out in connexion with the individual experiments, this depression varies in duration with the different conditions offered. Plainly a transfer from $20.0^{\circ}$ to $1.0^{\circ} \mathrm{C}$. can be followed by no recovery, since, at the lower temperature, activity is practically suspended. A transfer in the reverse direction, however, is usually followed by a more or less marked depression of growth. This depression-period may vary in length from a few minutes to days, and, as has been seen in cases, the normal growth may not be regained.

The duration of this phenomenon depends (I) on the location of the lower temperature-limit to which the objects are exposed, and (2) on the duration of this exposure.

In a general way, it may be said that the lower the temperature-limit lies, the shorter the exposure sufficient to produce a depressed growth upon the return to the higher temperature. By shortening the period of exposure sufficiently, the depression may be so far reduced that its presence is not to be detected. Otherwise stated, a certain minimum 
Turgor and of Temperature on Growth. $4 \mathrm{OI}$

exposure is necessary to induce a depression. The duration of this depression increases roughly with the increased period of exposure.

The character of this occurrence seems to suggest a cause that one would regard as probably present. It seems plain that in the depression-period we have the reaction of the living organisms to a stimulus, here represented by the exposure to the low temperature and the shock of the sudden change.

It is not to be forgotten that a prolonged stay in a low temperature may induce in the plants a sort of pathological condition, and that we are then no longer dealing with normal objects ${ }^{1}$.

When changes were made between $18^{\circ}$ and $30^{\circ} \mathrm{C}$. as extremes, evidence of retardation following was not to be detected. The modified rate of elongation following a change of temperature would be fully accounted for by the changes of turgor-pressure having their origin in the differences of temperature. The irritable response to change, if present, is lost in the accidental irregularities of growth. In this case, we must agree with Pedersen ${ }^{2}$, that temperature-change as such has no perceivable effect on plant-growth.

\section{Recapitulation.}

The most important results of the second part of this paper are here briefly summed up.

Following a sudden fall or a sudden rise of the temperature between $\mathrm{I} 8.0^{\circ}-2 \mathrm{I} \cdot 0^{\circ}$ and $0.5^{\circ}-\mathrm{I} \cdot 5^{\circ} \mathrm{C}$. as extremes, the first effect seen is a slight turgor-change due to physical causes, producing, or tending to produce, a shortening in length if the temperature be lowered; or, in case the temperature be raised, producing an elongation.

Following this mechanical action, a period of depressed growth usually follows. The duration of the depression-period depends on the position of the lower temperature-limit and

1 Pfeffer, Druck und Arbeitsleistung, p. 354.

${ }^{2}$ Pedersen, loc. cit. 
on the length of time of exposure to this temperature. The depression is regarded as the irritable response to the stimulus furnished by the exposure to the low temperature followed by the sudden change to the higher degree. The duration of the depression may be increased by lowering the minimum temperature-limit and by lengthening the period of exposure. An exposure to the lower temperature for less than a certain period of time is followed by no noticeable depression.

Changes of temperature between $18^{\circ}$ and $30^{\circ} \mathrm{C}$. as extremes seem to be followed by turgor-changes only. That no momentary depression of the growth-rate takes place is hardly to be asserted. Indeed, it is likely that such takes place, but by reason of the slightness of amplitude becomes lost in the more striking spontaneous changes. It is also to be borne in mind that a slight uncontrolled interval follows the change of temperature. That in this interval a slight effect might have escaped observation is also not out of the question.

In conclusion, I wish to express my sincere gratitude to Professor Pfeffer, and to his assistants, especially to Dr. Paul Klemm, for many kind suggestions and helpful criticisms; also for free access to the rich resources of the Institute.

Botanical Institute, Leipsic, December, I894. 


\section{$2 \mathrm{BHL}$ Biodiversity Heritage Library}

True, Rodney H. 1895. "On the influence of sudden changes of turgor and of temperature on growth." Annals of botany 9, 365-402. https://doi.org/10.1093/oxfordjournals.aob.a090744.

View This Item Online: https://www.biodiversitylibrary.org/item/233478

DOI: https://doi.org/10.1093/oxfordjournals.aob.a090744

Permalink: https://www.biodiversitylibrary.org/partpdf/318383

\section{Holding Institution}

Smithsonian Libraries

\section{Sponsored by}

Biodiversity Heritage Library

\section{Copyright \& Reuse}

Copyright Status: Not in copyright. The BHL knows of no copyright restrictions on this item.

This document was created from content at the Biodiversity Heritage Library, the world's largest open access digital library for biodiversity literature and archives. Visit BHL at https://www.biodiversitylibrary.org. 